BADANIA I ROZWÓJ

mgr inż. Krzysztof Isajenkoa)*, mgr Barbara Piotrowskaa), mgr Olga Stawarza), dr Aneta Łukaszek-Chmielewska ${ }^{\text {b) }}$, mgr Sylwia Krawczyńskac)

\author{
a) Centralne Laboratorium Ochrony Radiologicznej / The Central Laboratory for Radiological Protection \\ b) Szkoła Główna Służby Pożarniczej / The Main School of the Fire Service \\ c) Centrum Naukowo-Badawcze Ochrony Przeciwpożarowej im. J. Tuliszkowskiego - Państwowy Instytut Badawczy / Scientific and \\ Research Centre for Fire Protection - National Research Institute \\ *Autor korespondencyjny / Corresponding author: isajenko@clor.waw.pl
}

\title{
Analiza dynamiki skażenia gleby naturalnymi i sztucznymi radionuklidami w województwie opolskim po awarii elektrowni jądrowej w Czarnobylu
}

An Analysis of The Dynamics of Soil Contamination Density in the Opole Province by Natural and Artificial Radionuclides after the Chernobyl Nuclear Power Plant Accident

\section{Анализ динамики загрязнения почвы естественными и искусственными радионуклидами в Опольском воеводстве после аварии на Чернобыльской АЭС}

\begin{abstract}
ABSTRAKT
Wprowadzenie: W wyniku awarii reaktora elektrowni jądrowej w Czarnobylu na Ukrainie w 1986 roku doszło do niekontrolowanego uwolnienia substancji radioaktywnych. Województwo opolskie należy do obszarów, na których nastąpiła największa kumulacja skażenia powierzchniowego izotopami promieniotwórczymi. Deszczowa pogoda panująca na tym obszarze podczas przechodzenia radioaktywnej chmury wpłynęła na zatrzymanie się w komponentach środowiska różnych izotopów promieniotwórczych. Cel: W opracowaniu skupiono uwagę na przedstawieniu dynamiki zmian wartości stężenia powierzchniowego cezu ${ }^{137}$ Cs w glebie Opolszczyzny na przestrzeni prawie trzydziestu lat od awarii czarnobylskiej.

Projekt i metody. Duże znaczenie dla oceny zmian wartości stężenia powierzchniowego ${ }^{137}$ Cs w glebie z określonego punktu poboru próbek ma stan mikrośrodowiska. Nie może być ono zniekształcone lub zmienione przez działalność człowieka. Istotne jest również to, aby sposób pobierania próbek był ustalony i powtarzalny, a ich przygotowanie do pomiaru w laboratorium odbywało się według ściśle określonych procedur. Po odpowiednim przygotowaniu próbki są poddawane pomiarom spektrometrycznym na detektorze półprzewodnikowym HPGe oraz analizie promieniowania gamma za pomocą oprogramowania Genie-2000.

Wyniki: Podczas analizy widm promieniowania gamma w próbkach gleby stwierdzono obecność naturalnych izotopów ${ }^{40} \mathrm{~K}$, ${ }^{226} \mathrm{Ra} \mathrm{i}^{228} \mathrm{Ac}$ oraz sztucznych izotopów ${ }^{134} \mathrm{Cs}$ (rejestrowany do 1996 r.) i ${ }^{137} \mathrm{Cs}$ (rejestrowany do dziś). W artykule przedstawiono rezultaty pomiarów stężeń powierzchniowych ${ }^{137} \mathrm{Cs}$ i stężeń naturalnych radionuklidów ${ }^{40} \mathrm{~K},{ }^{226} \mathrm{Ra}$ i ${ }^{228} \mathrm{Ac}$ w glebie woj. opolskiego dla próbek pochodzących z okresu 1988-2014.

Wnioski: Zgodnie z przewidywaniami na przestrzeni prawie 30 lat od awarii w Czarnobylu stężenie ${ }^{137} \mathrm{Cs}$ w glebie stopniowo maleje. Jest to związane z rozpadem izotopu oraz jego przenikaniem w głębsze warstwy gleby. Natomiast stężenie radionuklidów naturalnych w badanych miejscowościach utrzymuje się na podobnym poziomie. Wskazana jest kontynuacja pomiarów, w celu sprawdzenia, jak maleje stężenie powierzchniowe ${ }^{137} \mathrm{Cs}$ w glebie i kiedy jego wartość znajdzie się poniżej progu detekcji. Należałoby także wybrać kilka punktów poboru gleby (także na Opolszczyźnie) w celu zbadania, jak ${ }^{137}$ Cs przeniknął w głębsze warstwy gleby (pobór z warstwy 25 cm). Słowa kluczowe: awaria reaktora, Czarnobyl, radioaktywność gleby, ${ }^{137} \mathrm{Cs},{ }^{40} \mathrm{~K},{ }^{226} \mathrm{Ra},{ }^{228} \mathrm{Ac},{ }^{228} \mathrm{Th}$, województwo opolskie Typ artykułu: studium przypadku - analiza zdarzeń rzeczywistych
\end{abstract}

Przyjęty: 21.03.2017; Zrecenzowany: 23.05.2017; Opublikowany: 30.06.2017

Procentowy wkład merytoryczny: K. Isajenko - 30\%, B. Piotrowska - 25\%, O. Stawarz - 25\%, A. Łukaszek-Chmielewska - 10\%, S. Krawczyńska - 10\%; Proszę cytować: BiTP Vol. 46 Issue 2, 2017, pp. 42-54, doi: 10.12845/bitp.46.2.2017.3;

Artykuł udostępniany na licencji CC BY-NC-SA 4.0 (https://creativecommons.org/licenses/by-nc-sa/4.0/).

\section{ABSTRACT}

Introduction: In 1986 there was an accident in the reactor at the Chernobyl Nuclear Power Plant in Ukraine which caused an uncontrolled release of radioactive substances. The Opole province in Poland is one of the areas which suffered the greatest accumulation of surface contamination with radionuclides. As a result of rainy weather in this area during the transition of the radioactive cloud, various radioisotopes remained in the environmental components. 
Objective: The study focuses on the dynamic changes in the surface concentration of cesium ${ }^{137} \mathrm{Cs}$ in soil samples from the Opole province, which have been measured for nearly thirty years since the Chernobyl disaster.

Method: The condition of the microenvironment is very important for the assessment of changes in ${ }^{137} \mathrm{Cs}$ surface concentration for the soil taken from the same sampling point, so the microenvironment cannot be distorted or changed by human activity. The method of sampling must be fixed and repeatable, and the preparation of samples for measurement in the laboratory should be conducted according to strict procedures. After proper preparation, samples are measured spectrometrically on a HPGe semiconductor detector and then an analysis of gamma radiation is done with Genie-2000 software.

Results: During the gamma-radiation spectrum analysis of the soil samples, the surface concentration of natural isotopes ${ }^{40} \mathrm{~K}, 2^{26} \mathrm{Ra}$ and ${ }^{228} \mathrm{Ac}$ and of artificial isotopes ${ }^{134} \mathrm{Cs}$ (reported till 1996) and ${ }^{137} \mathrm{Cs}$ (reported to the present) was detected. The article presents the results of ${ }^{137} \mathrm{Cs}$ surface concentration measurements, as well as the concentration of ${ }^{40} \mathrm{~K},{ }^{226} \mathrm{Ra}$ and ${ }^{228} \mathrm{Ac}$ natural radionuclides in the soil of the Opole province from samples measured in the period $1988-2014$.

Conclusions: As expected, for the nearly 30 years since the failure of the Chernobyl NPP, the concentration of ${ }^{137} \mathrm{Cs}$ in the soil has been gradually decreasing as a result of isotope decay and its penetration into the deeper layers of the soil. On the other hand, the concentration of natural radionuclides is at a similar level for the same sampling points. In the future it will be useful to continue measuring to see how the surface concentration of ${ }^{137} \mathrm{Cs}$ for soil is decreasing and when its value will be below the detection threshold. It would be also good to select several sampling points (also in the Opole province) in order to investigate how ${ }^{137} \mathrm{Cs}$ has penetrated into the deeper layers of the soil (a 25-cm layer).

Keywords: reactor accident, Chernobyl, soil radioactivity, ${ }^{137} \mathrm{Cs},{ }^{40} \mathrm{~K},{ }^{226} \mathrm{Ra},{ }^{228} \mathrm{Ac},{ }^{228} \mathrm{Th}$, Opole province

Type of article: case study - analysis of actual events

Received: 21.03.2017; Reviewed: 23.05.2017; Published: 30.06.2017;

Percentage contribution: K. Isajenko - 30\%, B. Piotrowska - 25\%, O. Stawarz - 25\%, A. Łukaszek-Chmielewska - 10\%, S. Krawczyńska - 10\%;

Please cite as: BiTP Vol. 46 Issue 2, 2017, pp. 42-54, doi: 10.12845/bitp.46.2.2017.3;

This is an open access article under the CC BY-NC-SA 4.0 license (https://creativecommons.org/licenses/by-nc-sa/4.0/).

\section{АННОТАЦИЯ}

Введение: В результате аварии реактора на Чернобыльской атомной электростанции в Украине в 1986 году произошёл неконтролируемый выброс радиоактивных вешеств. Опольское воеводство принадлежит к территориям с наибольшим накоплением поверхностного загрязнения радиоакти́вными нукли́дами. В результате дождливой погоды в этом районе во время прохождения радиоактивного облака в окружаюшую среду проникли различные радиоактивные изотопы.

Цель: В работе авторы сосредоточились на представлении динамики изменения значений поверхностной концентрации цезия ${ }^{137} \mathrm{C}$ в в почве Опольского воеводства за период почти тридцати лет от аварии на Чернобыльской АЭС.

Проект и методы: Большое значение для оценки изменений значений поверхностной концентрации цезия-137 в почве, собранной в конкретном пункте сбора образцов, имеет факт, что микросреда не может быть искажена или изменена человеческой деятельностью. Кроме того, важно, чтобы способ сбора образцов был фиксированный и повторяюшийся, а подготовка образцов для измерений в лаборатории проводилось в соответствии со строгими процедурами. После соответствуюшей обработки образцы подвергаются спектрометрическим измерениям на полупроводниковым детекторе HPGe и анализу гамма-лучей с помошью программного обеспечения Genie-2000.

Результаты: В ходе анализа гамма-спектров образцов почвы было обнаружено наличие естественных изотопов ${ }^{40} \mathrm{~K}$, ${ }^{226} \mathrm{Ra}$ и ${ }^{228} \mathrm{Ac}$ и искусственных изотопов ${ }^{134} \mathrm{Cs}$ (регистрируемый до 1996) и ${ }^{137} \mathrm{Cs}$ (зарегистрированный по сегодняшний день). В статье представлены результаты измерений поверхностной концентраций ${ }^{137} \mathrm{Cs}$ и концентрации естественных радионуклидов ${ }^{40} \mathrm{~K}$, ${ }^{226} \mathrm{Ra}$ и ${ }^{228} \mathrm{Ac}$ в почве в Опольском воеводстве для образцов из периода $1988-2014$. Выводы: Как и ожидалось, в течение почти 30 лет после аварии на Чернобыльской АЭС концентрация ${ }^{137}$ Сs в почве постепенно уменьшалась в результате распада изотопа и его проникновение в более глубокие слои почвы. В то время как концентрация естественных радионуклидов остается на том же уровне в рассматриваемых городах. В будушем желательно продолжить измерения, чтобы увидеть, как уменьшается поверхностная концентрация ${ }^{137} \mathrm{Cs}$ в почве и когда его величина будет находиться ниже порога обнаружения. Следует также выбрать несколько пунктов сбора образцов почвы (в том числе в Опольском воеводстве) для того, чтобы исследовать, как ${ }^{137} \mathrm{Cs}$ проникал в глубокие слои почвы (отбор из слоя на 25 см).

Ключевые слова: авария реактора, Чернобыль, радиоактивность почвы, ${ }^{137} \mathrm{Cs},{ }^{40} \mathrm{~K},{ }^{226} \mathrm{Ra},{ }^{228} \mathrm{Ac},{ }^{228} \mathrm{Th}$, Опольское воеводство

Вид статьи: исследование случая - анализ реальных событий

Принята: 12.05.2017; Рецензирована: 12.05.2017; Опубликована: 30.06.2017;

Процентное соотношение участия в подготовке статьи: K. Isajenko - 30\%, B. Piotrowska - 25\%, O. Stawarz - 25\%, A. Łukaszek-Chmielewska - 10\%, S. Krawczyńska - 10\%;

Просим ссылаться на статью следуюшим образом: BiTP Vol. 46 Issue 2, 2017, pp. 42-54, doi: 10.12845/bitp.46.2.2017.3;

Настояшая статья находится в открытом доступе и распространяется в соответствии с лицензией CC BY-NC-SA 4.0

(https://creativecommons.org/licenses/by-nc-sa/4.0/). 


\section{Wstęp}

Każdego dnia człowiek narażony jest na niewielkie dawki promieniowania jonizującego pochodzącego $z$ kosmosu, a także od radionuklidów stanowiących naturalne tło promieniowania, zróżnicowane w zależności od warunków środowiskowych. Lokalne promieniowanie jonizujące zależy nie tylko od stężeń izotopów naturalnych, takich jak potas ${ }^{40} \mathrm{~K}$, rad ${ }^{226} \mathrm{Ra}$, aktyn ${ }^{228} \mathrm{Ac}$ czy tor ${ }^{228} \mathrm{Th}$. Znaczący jest także udział sztucznych izotopów powstałych na skutek aktywnej działalności człowieka. W środowisku znajduje się przede wszystkim cez ${ }^{137} \mathrm{Cs}$, którego wysokie stężenia są odnotowywane w Polsce od ponad 30 lat.

26 kwietnia 1986 roku doszło do awarii elektrowni jądrowej w Czarnobylu, a już dwa dni po wypadku regionalna stacja pomiarowa Służby Pomiaru Skażeń Promieniotwórczych w Mikołajkach zarejestrowała kilkukrotnie zwiększony poziom promieniowania gamma i około 700 razy większy niż normalny poziom promieniowania beta. W wyniku intensywnych lokalnych opadów deszczu i zmiany kierunku wiatru, najsilniej skażonym rejonem Polski stał się obszar dzisiejszego województwa opolskiego oraz części województwa dolnośląskiego [1], [2], [3]. Podwyższona wartość stężenia powierzchniowego ${ }^{137} \mathrm{Cs} w$ środowisku tego regionu jest rejestrowana aż do dziś. Obraz obecnego powierzchniowego skażenia gleby w Polsce przedstawiono na rycinie 1 .

\section{Introduction}

Every day human beings are exposed to small amounts of ionising radiation, not only from space, but also coming from radionuclides constituting the natural radiation background, which varies according to environmental conditions. Local ionising radiation depends not only on natural isotope concentration such as potassium ${ }^{40} \mathrm{~K}$, radium ${ }^{226} \mathrm{Ra}$, actinium ${ }^{228} \mathrm{Ac}$ or thorium ${ }^{228} \mathrm{Th}$. There is also a significant share of artificial isotopes, created as a result of human activities. Mainly, there is cesium ${ }^{137} \mathrm{Cs}$ in the environment, which high concentration has been observed in Poland for more than 30 years.

On 26 April 1986 there was an accident in the reactor at the Chernobyl Nuclear Power Plant, and, as early as two days later, the local testing station of the Radioactive Contamination Measurement Services in Mikołajki registered a several-times higher level of gamma radiation, and beta radiation about 700 times higher than the average level. As a result of local heavy rains and a change in wind direction, the most contaminated Polish region became the today area of the Opole province and part of the Lower Silesia province, [1], [2], [3]. The increased contamination of the surface concentration of ${ }^{137} \mathrm{Cs}$ in the region's environment has been monitored to this day. Figure 1 presents the current surface contamination in Poland.

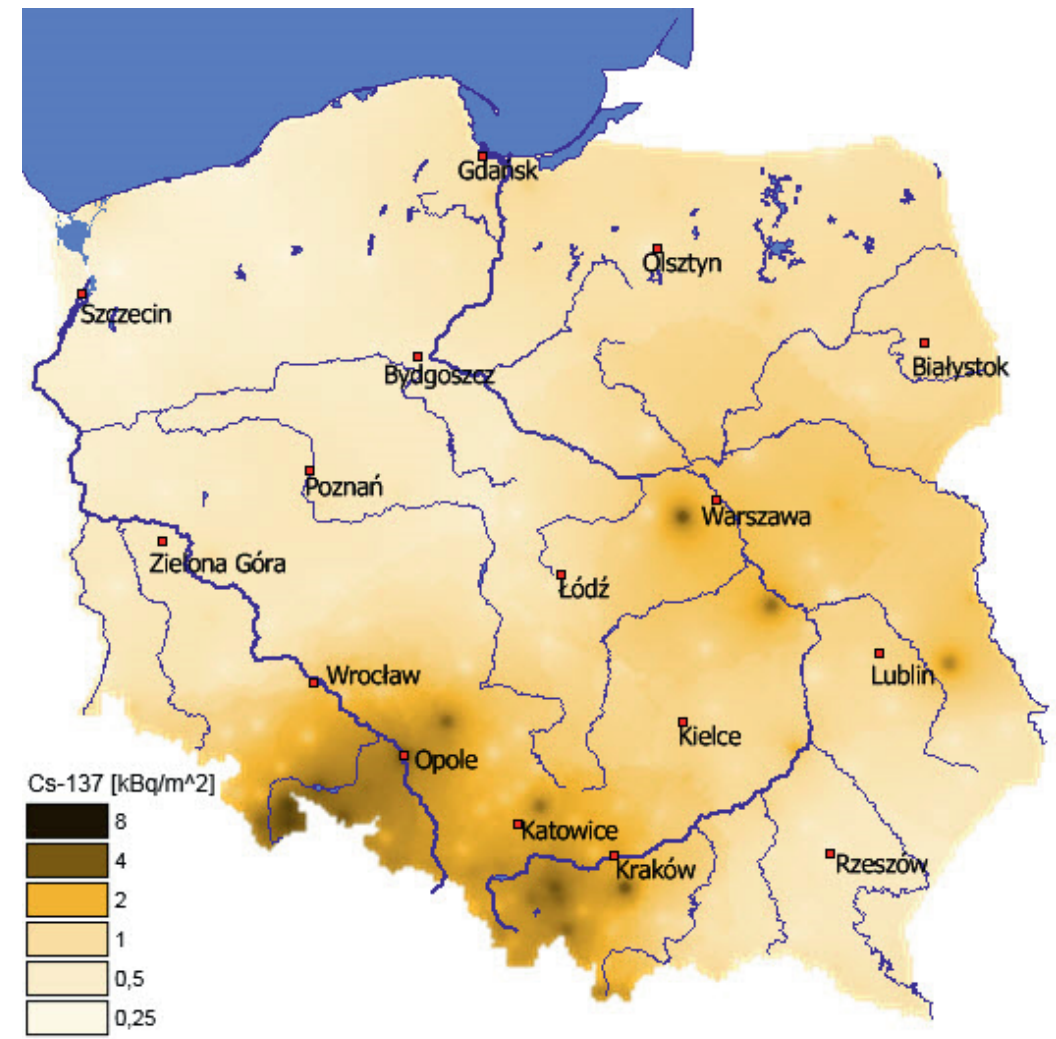

Rycina 1. Powierzchniowe stężenie ${ }^{137} \mathrm{Cs}$ w Polsce $\left(\mathrm{w} \mathrm{kBq} / \mathrm{m}^{2}\right)$ w próbkach gleby pobranej w październiku 2014 roku

Figure 1. The surface concentrations of cesium ${ }^{137} \mathrm{Cs}\left(\mathrm{kBq} / \mathrm{m}^{2}\right)$ in samples of soil collected in October 2014

Źródło: Opracowanie własne.

Source: Own elaboration. 
Wszystkie dane wykorzystane w artykule pochodzą z systemu Państwowego Monitoringu Środowiska, podsystemu Monitoringu Promieniowania Jonizującego (Główny Inspektorat Ochrony Środowiska) [4], [5], [6], [7].

Od 1988 roku Centralne Laboratorium Ochrony Radiologicznej na zlecenie Głównego Inspektoratu Ochrony Środowiska sukcesywnie przeprowadza kontrolę środowiska poprzez analizę próbek gleby z ponad 250 punktów pomiarowych z terenu całej Polski (a w początkowych latach z ponad 350 punktów pomiarowych). W związku z niekontrolowanym silnym skażeniem Opolszczyzny rejon ten jest wyjątkowo inspekcjonowany pod względem stężenia naturalnych pierwiastków promieniotwórczych oraz sztucznego cezu ${ }^{137} \mathrm{Cs}$.

$\mathrm{Na}$ terenie województwa opolskiego wyznaczonych jest 10 punktów poboru próbek gleby: Głuchołazy, Gołuszowice-Głubczyce, Grodków, Korfantów, Namysłów, Opole, Otmuchów, Prudnik, Stare Olesno i Sukowice-Zakrzów. Lokalizację punktów poboru na terenie województwa opolskiego przedstawiono na rycinie 2 .
All data used in the article come from the State Environment Monitoring system, sub-system lonising Radiation Monitoring (the Chief Inspectorate of Environmental Protection) [4], [5], [6], [7].

Since 1988, the Central Laboratory for Radiological Protection, by order of the Chief Inspectorate of Environmental Protection, has been controlling the environment by soil sample analysis from over 250 sampling points all over Poland (in the first years from over 350 sampling points). Because of the uncontrolled heavy contamination of the Opole province, this region is thoroughly inspected as far as the natural radioactive elements and artificial cesium ${ }^{137} \mathrm{Cs}$ are concerned.

In the Opole province there are 10 soil sampling points: Głuchołazy, Gołuszowice-Głubczyce, Grodków, Korfantów, Namysłów, Opole, Otmuchów, Prudnik, Stare Olesno and Sukowice-Zakrzów. Their locations are shown in Figure 2.

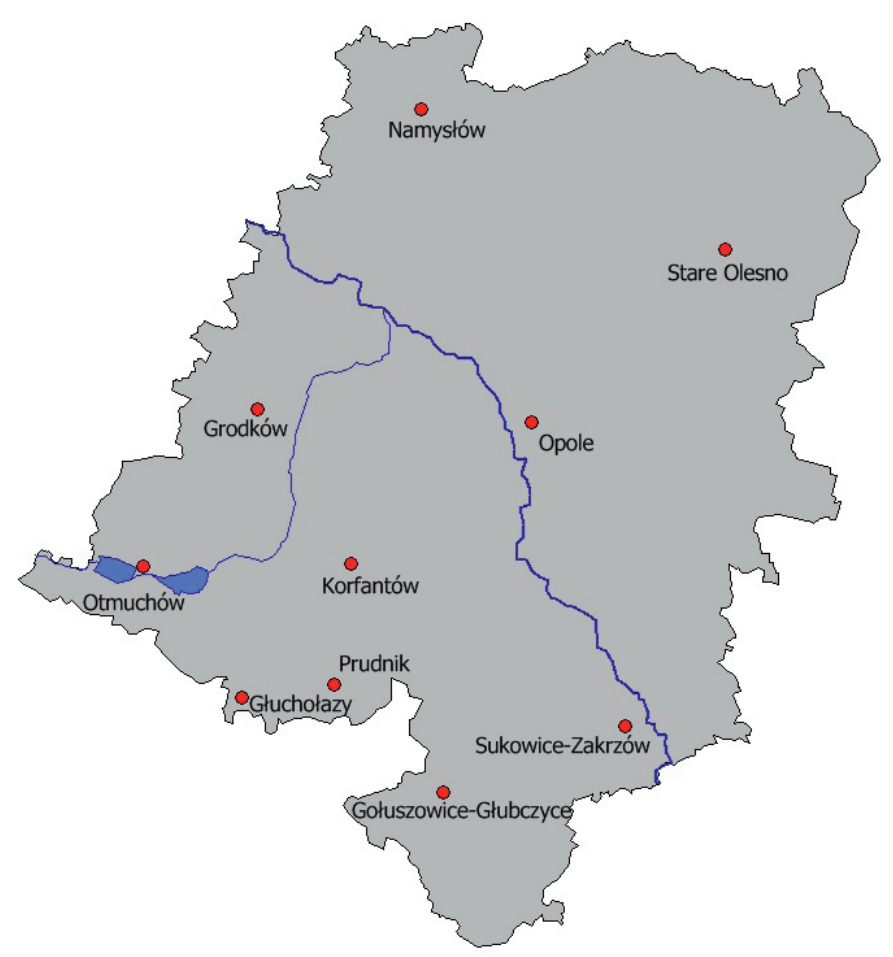

Rycina 2. Punkty poboru próbek gleby w woj. opolskim

Figure 2. The soil sampling points in the Opole province

Źródło: Opracowanie własne.

Source: Own elaboration.

\section{Część doświadczalna}

\section{Pobór i przygotowanie próbek}

Próbki gleby pobierano w ogródkach meteorologicznych stacji i posterunków IMGW. Każda próbka gleby została pobrana z głębokości $10 \mathrm{~cm}$ w postaci 6 porcji z punktów umieszczonych na obwodzie koła o promieniu $1 \mathrm{~m}$ oraz 1 porcji z punktu znajdującego

\section{Experiments}

\section{Sampling and sample preparation}

Soil sampling was conducted in weather stations and posts (the Institute of Meteorology and Water Management). Each sample was taken at a depth of $10 \mathrm{~cm}$ in the following manner: 6 portions from the points located on a 1-metre radius 
się w środku tego koła. Następnie zmieszane w jednym worku porcje $\mathrm{z}$ danego punktu poboru przekazywano do Centralnego Laboratorium Ochrony Radiologicznej. W laboratorium próbki gleby były suszone $w$ temperaturze pokojowej, a następnie przez 16 godzin w temperaturze $105^{\circ} \mathrm{C}$. Po wysuszeniu próbki były rozdrabniane, mieszane i przesypywane $w$ naczynia pomiarowe typu Marinelli o objętości 0,5 $\mathrm{dm}^{3}\left(\right.$ V próbki $\left.=0,45 \mathrm{dm}^{3}\right)$.

\section{Metodyka pomiaru}

Do oznaczenia stężeń radionuklidów w pobranych próbkach gleby zastosowana została metoda spektrometryczna (spektrometria promieniowania gamma). Próbki mierzono za pomocą detektorów półprzewodnikowych HPGe, połączonych z analizatorami DSA 1000 lub DSA 2000 przy czasie pomiaru $t=80000 \mathrm{~s}$.

\section{Omówienie wyników}

Podczas pierwszych pomiarów skażenia gleb w Polsce, przeprowadzonych w 1988 roku, stężenia cezu ${ }^{137} \mathrm{C}$ s o wartościach powyżej $20 \mathrm{kBq} / \mathrm{m}^{2}$ odnotowano w próbkach pochodzących z Opola, Otmuchowa i Starego Olesna. Najwyższą wartość stężenia powierzchniowego ${ }^{137} \mathrm{Cs}$ spośród wymienionych miejscowości odnotowano wówczas w Starym Oleśnie. Wynosiła ona $81,00 \mathrm{kBq} / \mathrm{m}^{2}$. Skażenie gleby w Polsce było silne do tego stopnia, że 30 lat po awarii w Czarnobylu radioaktywny cez jest nadal mierzalny w glebie, a najwyższe stężenia osiąga w próbkach pochodzących z województwa opolskiego.

Ciągła obecność ${ }^{137} \mathrm{Cs}$ wynika z jego stosunkowo długiego czasu połowicznego rozpadu, który wynosi 30,2 lat. Dla przykładu - inny radioaktywny izotop cezu $-{ }^{134} \mathrm{Cs}$ był rejestrowany tylko do $1996 \mathrm{r}$. Obecnie nie jest on wykrywalny w glebach (wartość jego stężenia znajduje się poniżej dolnej granicy detekcji), ponieważ ze względu na krótki okres połowicznego zaniku (2,06 lat) uległ już rozpadowi.

Stężenie cezu ${ }^{137} \mathrm{Cs}$ w powierzchniowej warstwie gleby z roku na rok systematycznie maleje wskutek rozpadu promieniotwórczego oraz wnikania w głębsze warstwy gleby. Z gleb leśnych radionuklid ten przechodzi korzeniami do drzew, krzewów i innych roślin. Największe stężenia cezu występują w podgrzybkach brunatnych (Xerocomus badius), jednak ich radioaktywność jest na tyle niegroźna, że dopiero spożycie przez człowieka co najmniej kilkudziesięciu kilogramów tych grzybów spowodowałoby otrzymanie dawki granicznej.

Wyniki pomiarów stężenia powierzchniowego ${ }^{137} \mathrm{Cs}\left[\mathrm{kBq} / \mathrm{m}^{2}\right]$ w próbkach gleby pobranych w woj. opolskim w latach 19882014 zestawiono w tabeli 1.

\section{Dyskusja nad metodami i wynikami}

Jak wynika z danych zamieszczonych w tabeli 1 wartości stężenia powierzchniowego ${ }^{137} \mathrm{Cs}$ na przestrzeni lat spadały stopniowo, by w ostatnich latach ustabilizować się na poziomie porównywalnym z wartościami uzyskanymi z pomiarów wykonanych dla próbek gleby pobranych w Warszawie, czyli ok. 1,5 kBq/m². Jedynie próbki pochodzące z Głuchołazów, Opola, Otmuchowa oraz Starego Olesna nadal wykazują większe stężenie powierzchniowe ${ }^{137} \mathrm{Cs}$ niż w glebie pobieranej w centralnej Polsce. Wartość średnia depozycji ${ }^{137} \mathrm{Cs}$ w glebie pobranej w 2014 roku wynosi dla Polski $1,33 \pm 0,12 \mathrm{kBq} / \mathrm{m}^{2}$, a dla woj. opolskiego $3,55 \pm 0,59 \mathrm{kBq} / \mathrm{m}^{2}$. wheel circumference and 1 portion from the point located in the middle of this wheel. Next, the portions from one sampling point, mixed in a sack, were transported to the Central Laboratory for Radiological Protection. In the laboratory, the soil samples were dried at an ambient temperature, and then at a temperature of $105^{\circ} \mathrm{C}$, for 16 hours. Having been dried, the samples were mixed and placed into $0.5 \mathrm{dm}^{3}$ Marinelli beakers (samples $V=0.45 \mathrm{dm}^{3}$ ).

\section{Measurement methodology}

The spectrometric method (the spectrometry of gamma radiation) was used to determine radionuclide concentration in the soil samples. The samples were measured with HPGe semiconductor detectors, connected to DSA 1000 or DSA 2000 analysers, with the measurement time $\mathrm{t}=80000 \mathrm{~s}$.

\section{Results}

During the first measurements of soil contamination in Poland, conducted in 1988, cesium ${ }^{137} \mathrm{Cs}$ concentration higher than $20 \mathrm{kBq} / \mathrm{m}^{2}$ was observed in Opole, Otmuchów and Stare Olesno. Among the above mentioned locations, the highest ${ }^{137} \mathrm{Cs}$ surface concentration was observed at that time in Stare Olesno; it equalled $81.00 \mathrm{kBq} / \mathrm{m}^{2}$. Soil contamination in Poland was so strong that 30 years after the accident in Chernobyl radioactive cesium is still measurable in the soil and reaches the highest concentrations in samples from the Opole province.

The constant presence of ${ }^{137} \mathrm{Cs}$ results from its long half-life value, which is 30.2 years. For instance, other radioactive cesium isotopes ${ }^{134} \mathrm{C}$ s were being reported only until 1996. Currently, this radionuclide is not detected in the soil (its concentration value is below the lower detection limit) as this isotope has decayed because of its short half-life (2.06 years).

The ${ }^{137} \mathrm{Cs}$ concentration in the surface layer of soil has been gradually decreasing as a result of radioactive decay and penetrating deeper soil layers. This radionuclide goes from forest soils to trees, bushes and other plants, through their roots. The highest concentration of cesium is in brown mushrooms (Xerocomus badius), but their radioactivity is harmless; humans would have to eat several dozens of kilos of those mushrooms to receive a limit dose.

The results of ${ }^{137} \mathrm{Cs}$ surface concentration measurements $\left[\mathrm{kBq} / \mathrm{m}^{2}\right]$ of soil samples taken in the Opole province in 19882014 are presented in Table 1.

Results and discussion

According to the data presented in Table $1,{ }^{137} \mathrm{Cs}$ surface concentration decreased gradually over the years and became stable at levels similar to the values of measurements of samples taken in Warsaw, which was about $1.5 \mathrm{kBq} / \mathrm{m}^{2}$. Only the samples from Głuchołazy, Opole, Otmuchów and Stare Olesno still showed ${ }^{137} \mathrm{Cs}$ surface concentrations higher than for the soil taken in central Poland. The average value of ${ }^{137} \mathrm{Cs}$ deposition in the soil taken in 2014 was $1.33 \pm 0.12 \mathrm{kBq} / \mathrm{m}^{2}$ for Poland and $3.55 \pm 0.59 \mathrm{kBq} / \mathrm{m}^{2}$ for the Opole province. 
Tabela 1. Zestawienie wyników pomiarów stężenia powierzchniowego ${ }^{137} \mathrm{Cs}$ w glebie w woj. opolskim w latach $1988-2014$

Table 1. A summary of ${ }^{137} \mathrm{Cs}$ surface concentration measurements in the soil in the Opole province in 1988-2014

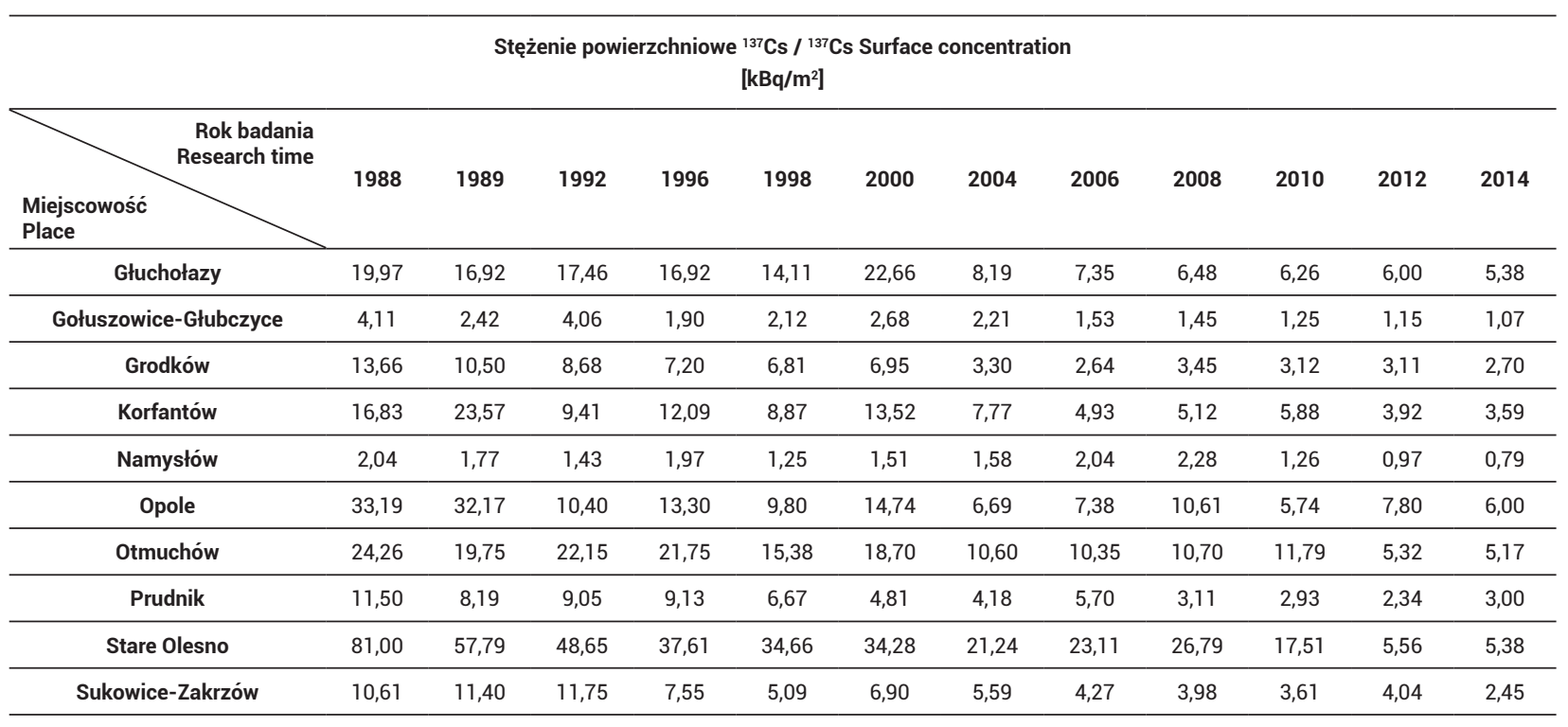

Źródło: Opracowanie własne.

Source: Own elaboration.

Zmiany stężenia powierzchniowego ${ }^{137} \mathrm{Cs}$ w glebie pobranej w woj. opolskim w latach 1988-2014 przedstawiono na rycinie 3. Podobnie jak z wyników zebranych w tabeli 1, wynika z niej, że wartość depozycji ${ }^{137}$ Cs systematycznie maleje, a maksymalną wartość w 1988 roku oraz najszybszy spadek można odnotować dla Starego Olesna. Na mapie (rycina 4) zaznaczono miejscowości woj. opolskiego o najwyższej depozycji ${ }^{137}$ Cs w 1988 roku.

Wartości stężeń promieniotwórczych ${ }^{137} \mathrm{Cs}$ dla próbek gleby pochodzących z czterech miast woj. opolskiego, które wykazywały początkowo najwyższe stężenia tego radionuklidu, zostały zebrane $w$ tabeli 2 . Zamieszczono w niej również wartości stężeń izotopów naturalnych ${ }^{226} \mathrm{Ra},{ }^{228} \mathrm{Ac} \mathrm{i}{ }^{40} \mathrm{~K}$, które, jak można zauważyć, niewiele zmieniały się na przestrzeni lat $z$ uwagi na długi okres połowicznego zaniku (np. czas życia izotopu potasu ${ }^{40} \mathrm{~K}$ wynosi $1,25 \times 10^{9}$ lat, radu ${ }^{226} \mathrm{Ra}$ - 1599 lat). Niewielkie zmiany stężenia potasu ${ }^{40} \mathrm{~K}$ można wytłumaczyć zjawiskami przypadkowymi np. nawożeniem pobliskich pól nawozami potasowymi i wiejącymi dość silnymi wiatrami w kierunku ogródka meteorologicznego, z którego pobierane były próbki gleby do badań. Wiatry takie mogły nanieść małą ilość potasu z nawożonych pól czy łąk. W przypadku aktynu ${ }^{228} \mathrm{Ac}$, jego wzrost (podobnie jak radu ${ }^{226} \mathrm{Ra}$ ) może być związany np. z niską temperaturą powietrza i większym niż w innych okresach ogrzewaniem domów za pomocą węgla. W czasie spalania węgla do atmosfery uwalnia się dużo radionuklidów naturalnych [8]. Ta zwiększona ilość promieniotwórczości naturalnej może mieć odzwierciedlenie w minimalnie większych stężeniach tych izotopów w powierzchniowej warstwie gleby.

Analiza wyników zebranych w tabeli 2 potwierdza, że wartość stężenia powierzchniowego ${ }^{137} \mathrm{Cs}$ w okresie $1988-2014$
The changes in ${ }^{137} \mathrm{Cs}$ surface concentration for the soil taken in the Opole province in 1988-2014 are presented in the chart (Figure 3). Similarly to results in Table 1, the chart shows that the ${ }^{137} \mathrm{Cs}$ deposition value has been decreasing, and the maximum value in 1988 and the fastest decrease could be observed for Stare Olesno. Figure 4 is a map showing the places in the Opole province which had the highest ${ }^{137} \mathrm{Cs}$ deposition in 1988.

Table 2 below presents the values of ${ }^{137} \mathrm{Cs}$ radioactivity concentration in soil samples in four towns in the Opole province which showed the highest concentration of this radionuclide. There were also values of natural isotopes ${ }^{226} \mathrm{Ra},{ }^{228} \mathrm{Ac}$ and ${ }^{40} \mathrm{~K}$ concentration which, as can be observed, changed only slightly over the years due to their long halflife (e.g. the life span of ${ }^{40} \mathrm{~K}$ potassium is $1.25 \times 10^{9}$ years and ${ }^{226} \mathrm{Ra}$ radium 1599 years). Minor changes in the ${ }^{40} \mathrm{~K}$ potassium concentration could be explained with accidental events, e.g. fertilising nearby fields with potassium fertilisers, or quite strong winds blowing into the direction of the weather post from which the soil samples were taken. Such winds could have transported a little potassium from the fertilised fields and meadows. As far as ${ }^{228} \mathrm{Ac}$ actinium is concerned, its increase (similarly to ${ }^{226} \mathrm{R}$ a radium) might have resulted from low air temperature and, greater than in other seasons, heating houses with coal. While burning coal, a lot of natural radionuclides are released into the atmosphere [8]. The increased amount of natural radioactivity can result in slightly higher concentrations of these isotopes in the surface soil layer.

Analysing the results gathered in Table 2, one can observe that the value of ${ }^{137} \mathrm{Cs}$ surface concentration in $1988-2014$ decreased significantly. In 1988, the maximum value of ${ }^{137} \mathrm{Cs}$ 
znacznie zmalała. W 1988 roku maksymalną wartość depozycji ${ }^{137} \mathrm{Cs}$ odnotowano dla próbki ze Starego Olesna $\left(81 \mathrm{kBq} / \mathrm{m}^{2}\right)$, natomiast w 2014 roku - dla próbki pochodzącej z Opola $\left(6 \mathrm{kBq} / \mathrm{m}^{2}\right)$. deposition was reported for the samples from Stare Olesno $\left(81 \mathrm{kBq} / \mathrm{m}^{2}\right)$, whereas in 2014 - for the sample from Opole $\left(6 \mathrm{kBq} / \mathrm{m}^{2}\right)$.

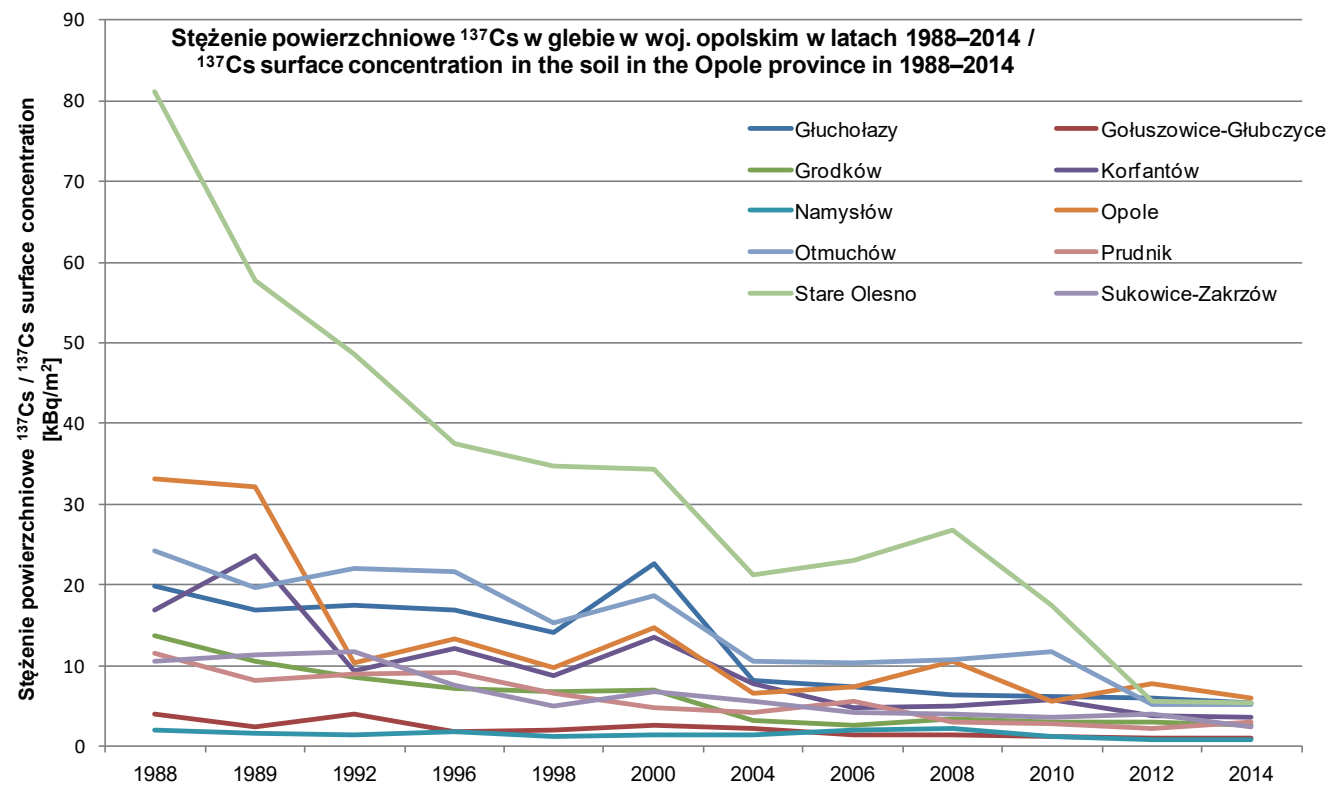

Rycina 3. Stężenie powierzchniowe ${ }^{137} \mathrm{Cs}$ w glebie w woj. opolskim w latach 1988-2014

Figure 3. ${ }^{137} \mathrm{Cs}$ surface concentrations in the soil in the Opole province in 1988-2014 Źródło: Opracowanie własne.

Source: Own elaboration.

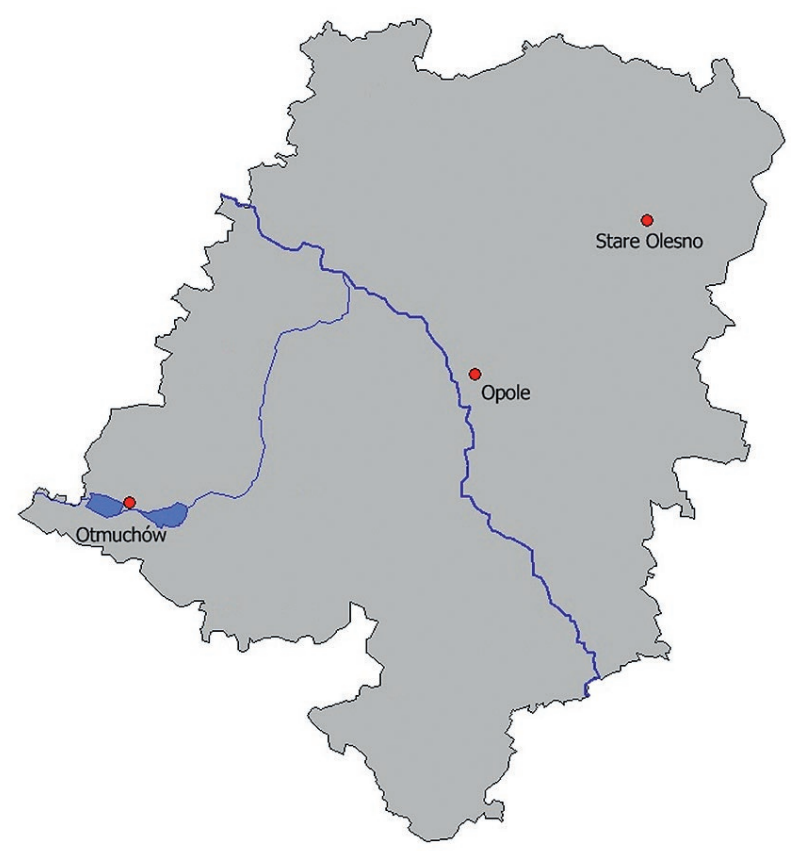

Rycina 4. Miejscowości woj. opolskiego o najwyższym stężeniu ${ }^{137} \mathrm{Cs}$ w glebie w 1988 roku

Figure 4. The places in the Opole province with the highest ${ }^{137} \mathrm{Cs}$ concentrations in the soil in 1988

Źródło: Opracowanie własne.

Source: Own elaboration. 
Tabela 2. Zestawienie wyników pomiarów stężeń promieniotwórczych ${ }^{137} \mathrm{Cs},{ }^{226} \mathrm{Ra},{ }^{228} \mathrm{Ac} \mathrm{i}{ }^{40} \mathrm{~K}$ w glebie w wybranych miejscowościach województwa opolskiego w latach 1988-2014

Table 2. Results summary of the measurements of ${ }^{137} \mathrm{Cs},{ }^{226} \mathrm{Ra},{ }^{228} \mathrm{Ac}$ and ${ }^{40} \mathrm{~K}$ radioactive concentrations in the soil in selected towns in the Opole province in 1988-2014

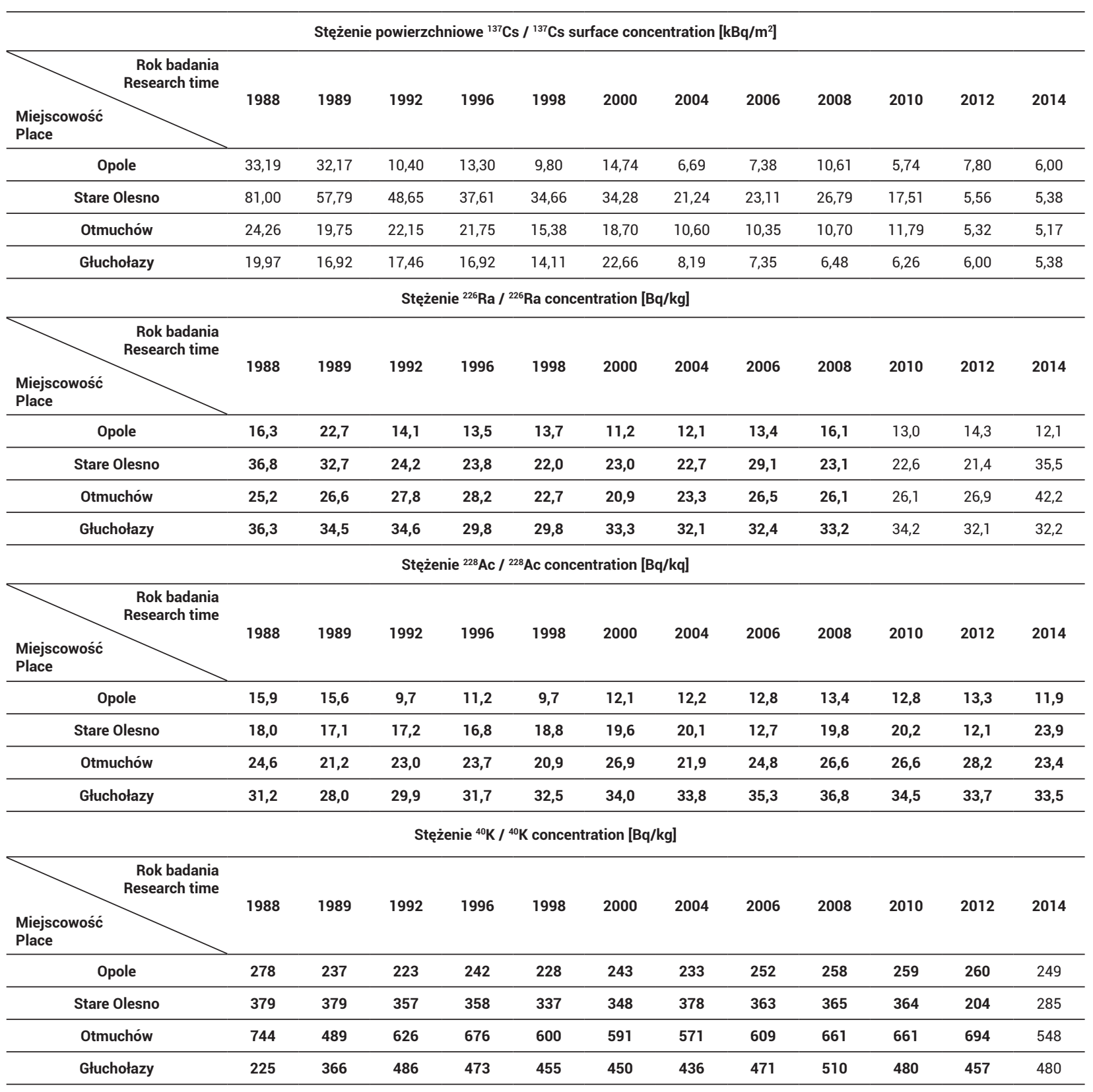

Źródło: Opracowanie własne.

Source: Own elaboration.

Stężenia radionuklidów naturalnych dla wybranych miejscowości woj. opolskiego utrzymują się na zbliżonym poziomie. Średnie stężenie ${ }^{40} \mathrm{~K}$ w glebie wyznaczone dla okresu 1988-2014 wynosi: 247 Bq/kg (Opole), 343 Bq/kg (Stare Olesno), 622 Bq kg (Otmuchów) oraz $441 \mathrm{~Bq} / \mathrm{kg}$ (Głuchołazy). Średnie stężenie ${ }^{226} \mathrm{Ra}$ w glebie w tym okresie wynosi: 14,4 Bq/kg (Opole), 26,4 Bq/kg (Stare Olesno), 26,9 Bq/kg (Otmuchów) oraz 32,9 Bq/kg (Głuchołazy). Średnie stężenie ${ }^{228} \mathrm{Ac} w$ glebie wyznaczone dla tego samego okresu wynosi: 12,6 Bq/kg (Opole), 18 Bq/kg (Stare Olesno), 24,3 Bq/kg (Otmuchów) i 32,9 Bq/kg (Głuchołazy).
Natural radionuclides concentration for the selected towns in the Opole province are at a similar level. The average ${ }^{40} \mathrm{~K}$ concentration for the soil set for the period of 1988-2014 was $247 \mathrm{~Bq} / \mathrm{kg}$ (Opole), $343 \mathrm{~Bq} / \mathrm{kg}$ (Stare Olesno), $622 \mathrm{~Bq} / \mathrm{kg}$ (Otmuchów) and $441 \mathrm{~Bq} / \mathrm{kg}$ (Głuchołazy). The average ${ }^{226} \mathrm{Ra}$ concentration in the soil was $14.4 \mathrm{~Bq} / \mathrm{kg}$ (Opole), $26.4 \mathrm{~Bq} / \mathrm{kg}$ (Stare Olesno), $26.9 \mathrm{~Bq} / \mathrm{kg}$ (Otmuchów) and $32.9 \mathrm{~Bq} / \mathrm{kg}$ (Głuchołazy). The average ${ }^{228} \mathrm{Ac}$ concentration for the soil set for the same period of time was $12.6 \mathrm{~Bq} / \mathrm{kg}$ (Opole), $18 \mathrm{~Bq} / \mathrm{kg}$ (Stare Olesno), 24.3 Bq/kg (Otmuchów) and 32.9 Bq/kg (Głuchołazy). 
Na wykresach przedstawionych na ryc. 5-8 zobrazowano zmiany stężenia ${ }^{137} \mathrm{Cs}$ oraz naturalnych izotopów w glebie pochodzącej z czterech wybranych miejscowości woj. opolskiego, pobranej w latach 1988-2014. Skażenie ${ }^{137}$ Cs w 1988 roku na terenie Starego Olesna było prawie 4-krotnie większe niż na terenie Otmuchowa i prawie 3-krotnie większe niż na terenie Opola.
Figures 5-8 show the changes of ${ }^{137} \mathrm{Cs}$ concentration and natural isotopes for the soil from four chosen towns of the Opole province, taken in $1988-2014 .{ }^{137} \mathrm{Cs}$ contamination in 1988 in Stare Olesno was almost 4 times higher than in the area of Otmuchów, and almost 3 times higher than in the area of Opole.

Stężenie powierzchniowe ${ }^{137}$ Cs w glebie w woj. opolskim w latach 1988-2014 /

${ }^{137} \mathrm{Cs}$ surface concentration in the soil in the Opole province in 1988-2014

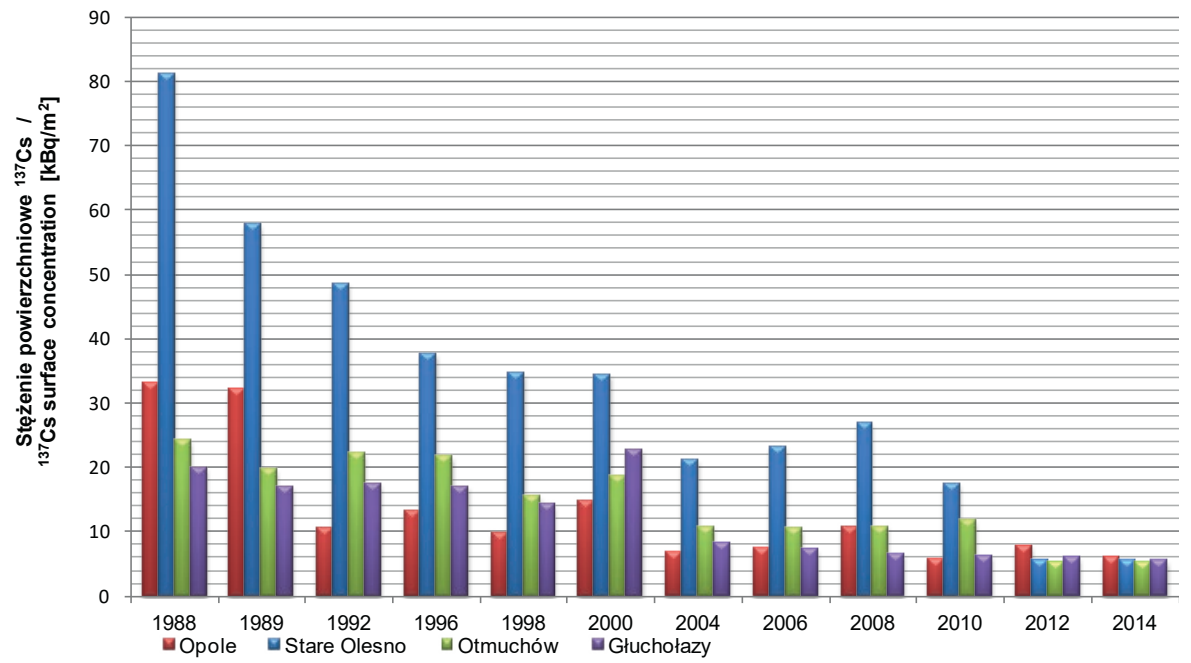

Rycina 5. Stężenie powierzchniowe ${ }^{137} \mathrm{Cs}$ w glebie w wybranych miejscowościach województwa opolskiego w latach $1988-2014$ Figure 5. ${ }^{137} \mathrm{C}$ s surface concentration in the soil in the selected places in the Opole province in 1988-2014

Źródło: Opracowanie własne.

Source: Own elaboration.

Stężenie ${ }^{226}$ Ra w glebie w woj.opolskim w latach 1988-2014 / ${ }^{226} \mathrm{Ra}$ concentration in the soil in the Opole province in 1988-2014

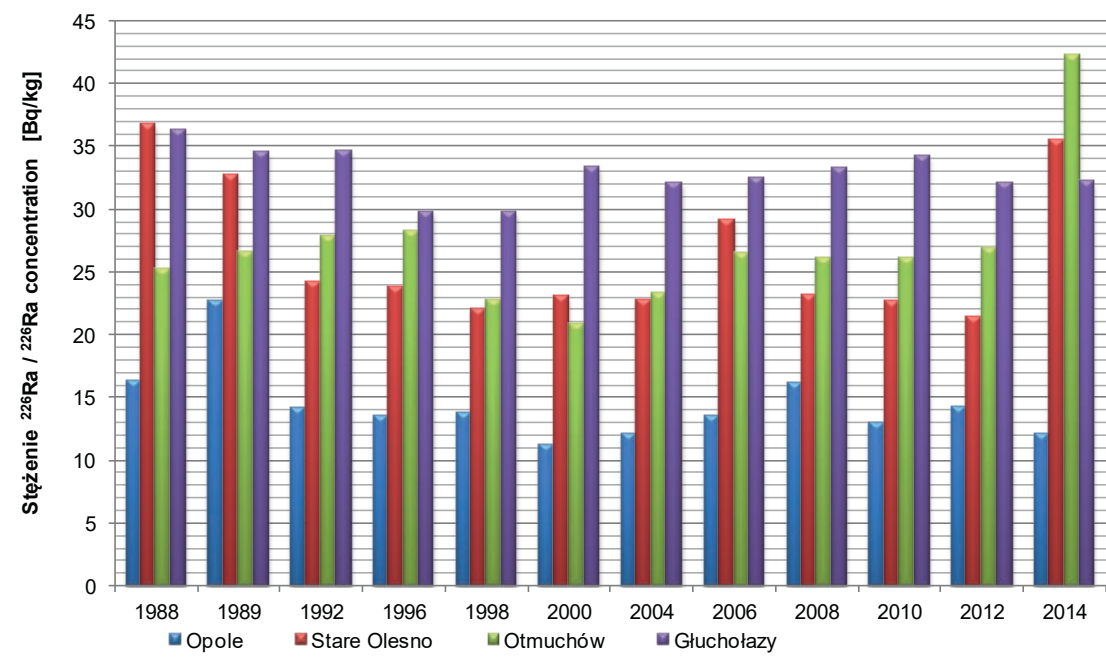

Rycina 6. Stężenie ${ }^{226}$ Ra w glebie w wybranych miejscowościach województwa opolskiego w latach 1988-2014

Figure 6. ${ }^{226} \mathrm{Ra}$ concentration in the soil in the Opole province in 1988-2014

Źródło: Opracowanie własne.

Source: Own elaboration. 
Najwyższe stężenie ${ }^{137} \mathrm{Cs}$ w Starym Oleśnie utrzymywało się aż do 2010 roku, po czym nastąpił spadek depozycji do wartości odpowiadającej pozostałym dwóm wybranym miejscowościom.

Wartości stężenia powierzchniowego ${ }^{137} \mathrm{Cs}$ w glebie na przestrzeni lat 1988-2014 systematycznie maleją. Dla próbek pobranych w 2014 roku w wybranych czterech miejscowościach Opolszczyzny są one zbliżone. Maksymalne stężenie zarejestrowano w próbce pobranej w Opolu.

Jak wynika z wykresu przedstawionego na rycinie 6 wartości stężeń ${ }^{226} \mathrm{Ra}$ dla poszczególnych miejscowości utrzymują się przez lata na podobnym poziomie. Wartość średnia stężenia ${ }^{226}$ Ra w latach 1988-2014 wynosi 27,2 Bq/kg dla woj. opolskiego oraz 25,6 Bq/kg dla całej Polski.
The highest ${ }^{137} \mathrm{Cs}$ concentrations in Stare Olesno were being reported until 2010, and then the depositions decreased to the values equal to the two other towns.

The values of ${ }^{137} \mathrm{Cs}$ surface concentration in the soil were systematically decreasing in the years 1988-2014. For the samples collected in 2014, these values for four selected towns in the Opole region remained at a similar level, with the maximum value recorded in the sample from Opole.

As can be seen in the diagram above (Figure 6), the ${ }^{226} \mathrm{Ra}$ concentrations for the respective towns remained at a similar level over the years. The average ${ }^{226} \mathrm{Ra}$ concentration in the years 1988-2014 was $27.2 \mathrm{~Bq} / \mathrm{kg}$ for the Opole province and $25.6 \mathrm{~Bq} / \mathrm{kg}$ for the whole of Poland.

Stężenie ${ }^{228}$ Ac w glebie w woj. opolskim w latach 1988-2014 / ${ }^{228} \mathrm{Ac}$ concentration in the soil in the Opole province in 1988-2014

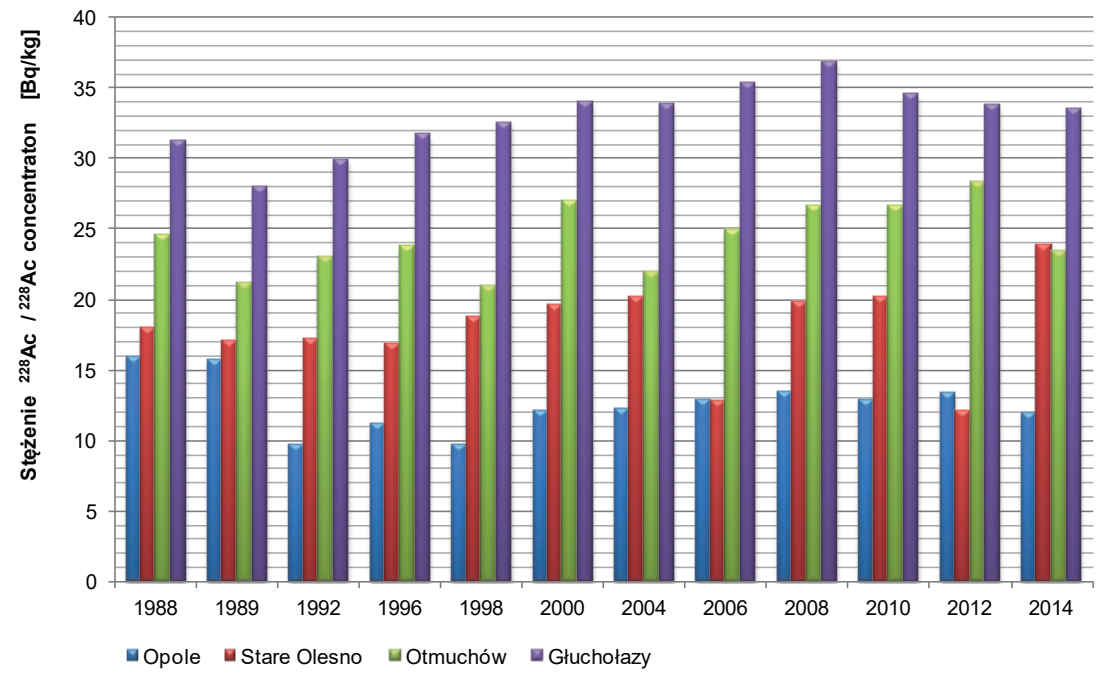

Rycina 7. Stężenie ${ }^{228} \mathrm{Ac}$ w glebie w wybranych miejscowościach województwa opolskiego w latach 1988-2014

Figure 7. ${ }^{228} \mathrm{Ac}$ concentration in the soil in the selected places in the Opole province in 1988-2014

Źródło: Opracowanie własne.

Source: Own elaboration.

Z wykresu znajdującego się na rycinie 7 można odczytać, że wartości stężeń ${ }^{228} \mathrm{Ac}$ w glebie pobranej w latach 1988-2014 z poszczególnych miejscowości woj. opolskiego utrzymują się na podobnym poziomie. Wartość średnia stężenia ${ }^{228} \mathrm{Ac}$ dla okresu 1988-2014 wynosi 25,0 Bq/kg dla woj. opolskiego oraz 22,3 Bq/kg dla całej Polski.

Z wykresu na rycinie 8 wynika, że wartości stężeń ${ }^{40} \mathrm{~K}$ w glebie poszczególnych miejscowości Opolszczyzny w analizowanych latach są do siebie zbliżone. Wartość średnia stężenia ${ }^{40} \mathrm{~K}$ obliczona dla okresu $1988-2014$ wynosi $448 \mathrm{~Bq} / \mathrm{kg}$ dla woj. opolskiego oraz $406 \mathrm{~Bq} / \mathrm{kg}$ dla całej Polski.
Analysing the chart in Figure 7, one might conclude that the values of ${ }^{228} \mathrm{Ac}$ concentrations for the soil taken in 1988-2014 from the towns in the Opole province were at similar levels. The average value of ${ }^{228} \mathrm{Ac}$ concentration for $1988-2014$ is $25.0 \mathrm{~Bq} / \mathrm{kg}$ for the Opole province and $22.3 \mathrm{~Bq} / \mathrm{kg}$ for the whole of Poland.

Having analysed the chart in Figure 8, one might conclude that the values of ${ }^{40} \mathrm{~K}$ concentration for particular towns of the Opole province were at a similar level within the period 19892014. The average value of ${ }^{40} \mathrm{~K}$ concentration counted for the above-mentioned period of time was $448 \mathrm{~Bq} / \mathrm{kg}$ for the Opole province and $406 \mathrm{~Bq} / \mathrm{kg}$ for the whole of Poland. 
Stężenie ${ }^{40} \mathrm{~K}$ w glebie w woj. opolskim w latach 1988-2014 I ${ }^{40} \mathrm{~K}$ concentration in soil in the Opole province in 1988-2014

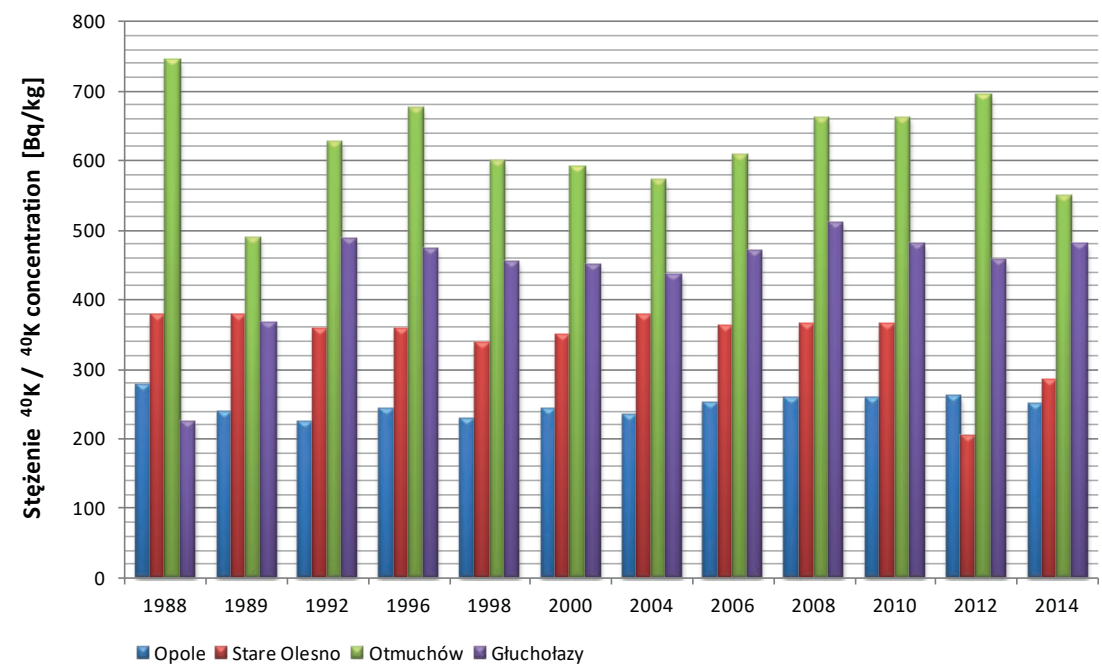

Rycina 8. Stężenie ${ }^{40} \mathrm{~K}$ w glebie w wybranych miejscowościach województwa opolskiego w latach 1988-2014

Figure $8 .{ }^{40} \mathrm{~K}$ concentration in the soil in the selected places in the Opole province in 1988-2014

Źródło: Opracowanie własne.

Source: Own elaboration.

\section{Podsumowanie}

Zgodnie z przewidywaniami wartość depozycji sztucznego radionuklidu ${ }^{137} \mathrm{Cs}$ w glebie sukcesywnie maleje w związku z rozpadem promieniotwórczym tego izotopu oraz częściowym wnikaniem w głębsze warstwy gleby. Wartość średnia stężenia powierzchniowego ${ }^{137} \mathrm{Cs}$ w glebie dla próbek pobranych w 2014 r. wynosi 3,55 kBq/m² dla woj. opolskiego i $1,33 \mathrm{kBq} / \mathrm{m}^{2}$ dla Polski. Na podstawie danych z 2014 roku narażenie osób z ogółu ludności Polski spowodowane obecnymi w środowisku sztucznymi izotopami promieniotwórczymi pozostaje na bardzo niskim poziomie. Dawka, którą mogą otrzymać mieszkańcy woj. opolskiego od sztucznych izotopów gamma promieniotwórczych, stanowi ułamek procenta wartości dawki granicznej dla ogółu ludności (wynoszącej $1 \mathrm{mSv}$ rocznie) [2]. Wskazane jest prowadzenie dalszych badań na terenie Opolszczyzny, ponieważ ${ }^{137} \mathrm{Cs}$ jako pozostałość po awarii w Czarnobylu, nadal jest rejestrowany w glebie na poziomie prawie trzykrotnie wyższym niż w pozostałych rejonach Polski. Ponadto wskazane jest przeprowadzenie pomiarów w próbkach gleby pobranej z głębokości $25 \mathrm{~cm}$, w celu poznania, jaka część tego izotopu przedostała się do głębszych warstw.

Stężenia naturalnych izotopów potasu ${ }^{40} \mathrm{~K}$, radu ${ }^{226} \mathrm{Ra}$ oraz aktynu ${ }^{228} \mathrm{Ac}$ w glebie utrzymują się na stałym poziomie. Wartości średnie stężeń obliczone dla okresu 19882014 dla próbek pobranych w woj. opolskim są porównywalne z wartościami średnimi dla Polski. Moc dawki od naturalnych izotopów promieniotwórczych dla mieszkańców Opolszczyzny wynosi $47,5 \mathrm{nGy} / \mathrm{h}$, co stanowi ok. $17 \%$ dawki od tła naturalnego.

\section{Conclusions}

As was predicted, the value of ${ }^{137} \mathrm{Cs}$ artificial radionuclide deposition has been gradually decreasing as a result of the radioactive decay of this isotope and its partial penetration into deeper soil layers. The average value of ${ }^{137} \mathrm{Cs}$ surface concentration for the samples taken in 2014 was $3.55 \mathrm{kBq} / \mathrm{m}^{2}$ for the Opole province and $1.33 \mathrm{kBq} / \mathrm{m}^{2}$ for the whole of Poland. According to data from 2014, the threat to the Polish population caused by the artificial radioactive isotopes present in the environment is at a very low level. A portion of the artificial radioactive gamma isotopes which can be received by the residents of the Opole province seems to be a fraction of the limit of the portion for the whole population (which is $1 \mathrm{mSv}$ a year) [2]. It is recommended to conduct further researches in the area of the Opole province, because ${ }^{137} \mathrm{Cs}$, as a remnant of the Chernobyl accident, is still being detected in the soil at the level almost three times higher than in other Polish regions. Furthermore, it would be advisable to conduct measurements of soil samples taken at a depth of $25 \mathrm{~cm}$ in order to learn which part of this isotope has penetrated into the deeper layers.

The concentrations of the natural isotopes ${ }^{40} \mathrm{~K}$ potassium, ${ }^{226} \mathrm{Ra}$ radium and ${ }^{228} \mathrm{Ac}$ actinium in soil are at a stable level. The average concentration values counted for 1988-2014 for the samples taken in the Opole province are comparable to the average values for Poland. The strength of a portion of natural radioactive isotopes for the residents of the Opole region is $47.5 \mathrm{nGy} / \mathrm{h}$, which constitutes $17 \%$ of the portion from the natural background. 
Artykuł został opracowany w ramach projektu pt. „Program do oceny ryzyka wystąpienia awarii w obiektach przemysłowych stwarzających zagrożenie poza swoim terenem" finansowanego przez Narodowe Centrum Badań i Rozwoju.

\section{Literatura / Literature}

[1] Jaworowski Z., Jak to z Czarnobylem było, „Wiedza i życie”, 1996, 5, [dok. elektr.] http://archiwum.wiz.pl/1996/96052000.asp [dostęp: 20.09.2016].

[2] Państwowa Agencja Atomistyki, http://www.paa.gov.pl/ [dostęp: 20.09.2016].

[3] Grudzka A., Co nam pozostało po Czarnobylu, [dok. elektr.] http:// www.nto.pl/magazyn/reportaz/art/4166081,co-nam-zostalo-poczarnobylu,id,t.html [dostęp: 20.09.2016].

[4] Isajenko K., Fujak M., Piotrowska B., Fujak M., Kuczbajska M., Ząbek A., Monitoring stężenia ${ }^{137} \mathrm{Cs}$ w glebie w latach 2008-2009, CLOR, Warszawa 2010.

MGR INŻ. KRZYSZTOF ISAJENKO - zastępca dyrektora Centralnego Laboratorium Ochrony Radiologicznej (CLOR) w Warszawie, kierownik Zakładu Dozymetrii CLOR, kierownik akredytowanego Laboratorium Pomiarów Promieniotwórczości Naturalnej, absolwent Wydziału Fizyki Technicznej i Matematyki Stosowanej Politechniki Warszawskiej (studia ukończone w 1987 roku z tytułem magistra inżyniera podstawowych problemów techniki), wieloletni członek Komisji Badania Morza Polskiej Akademii Nauk, wykładowca na Wydziale Fizyki Politechniki Warszawskiej, uczestnik wielu szkoleń dotyczących ochrony radiologicznej i bezpieczeństwa jądrowego (zarówno krajowych jak i zagranicznych), autor lub współautor wielu publikacji związanych z tą tematyką.

MGR BARBARA PIOTROWSKA - w 1996 r. ukończyła Wydział Fizyki na Uniwersytecie Warszawskim o specjalności fizyka jądrowa. Od 1 lipca 2009 roku pracownik Centralnego Laboratorium Ochrony Radiologicznej w Zakładzie Dozymetrii. Spektrometrią promieniowania gamma zajmuje się od 1996 roku. Obecnie bierze udział w pracach nad promieniotwórczością naturalną w surowcach i materiałach budowlanych oraz prowadzi szkolenia z tego zakresu badań. Jest kierownikiem ds. technicznych w Laboratorium Pomiarów Promieniotwórczości Naturalnej.

MGR OLGA STAWARZ - w 2001 roku ukończyła Wydział Fizyki na Uniwersytecie Warszawskim o specjalności fizyka cząstek elementarnych i oddziaływań fundamentalnych. Od 2002 roku pracuje w Centralnym Laboratorium Ochrony Radiologicznej w Zakładzie Dozymetrii. Początkowo zajmowała się pomiarami radonu i jego produktów rozpadu oraz pełniła funkcję Inspektora Ochrony Radiologicznej. Obecnie bierze udział w pracach związanych z monitoringiem radiologicznym środowiska, zajmuje się spektrometrią promieniowania gamma, pomiarami promieniotwórczości naturalnej surowców i materiałów budowlanych oraz pomiarami promieniowania i oceną dawek $w$ terenie, $w$ budynkach i miejscach pracy. Jest kierownikiem ds. jakości w Laboratorium Pomiarów Promieniotwórczości Naturalnej.
The article was written within the project "An IT tool for assessing a risk of accidents in industrial companies posing a threat outside their areas", financed by the National Centre for Research and Development.

[5] Isajenko K., Fujak M., Piotrowska B., Fujak M., Kuczbajska M., Kiełbasińska A., Monitoring stężenia ${ }^{137} \mathrm{Cs}$ w glebie w latach $2010-$ 2011, CLOR, Warszawa 2012.

[6] Isajenko K., Fujak M., Piotrowska B., Monitoring stężenia ${ }^{137} \mathrm{Cs}$ w glebie w latach 2012-2013, CLOR, Warszawa 2014.

[7] Isajenko K., Kardaś M., Wojtkowski K., Piotrowska B., Kwiatkowska I., Stawarz O., Ząbek A., Kiełbasińska A., Monitoring stężenia ${ }^{137} \mathrm{Cs}$ w glebie w latach 2014-2015, CLOR, Warszawa 2016.

[8] Piotrowska B., Fujak M., Isajenko K., Krawczyńska S., Building Materials Radioactivity in Poland, BiTP Vol. 44 Issue 4, 2016, pp. 151-158.

KRZYSZTOF ISAJENKO, M.Sc.Eng. - Deputy Director of the Central Laboratory for Radiological Protection (CLOR) in Warsaw, Head of the CLOR Department of Dosimetry, Head of the accredited Laboratory of Natural Radioactivity Measurements; graduated in 1987 from the Faculty of Technical Physics and Applied Mathematics at the Warsaw University of Technology (majoring as an MSc. Eng. in Fundamental Technological Research), a longtime member of the Commission for the Exploration of the Sea at the Polish Academy of Sciences, lecturer at the Faculty of Physics at the Warsaw University of Technology, participant in many training courses on radiation protection and nuclear safety (both domestic and foreign), the author or co-author of numerous publications dealing with these topics.

BARBARA PIOTROWSKA, M.Sc. - in 1996 graduated from the Faculty of Physics at Warsaw University with specialisation in nuclear physics. Since 1 July 2009 an employee of the Central Laboratory for Radiological Protection in the Department of Dosimetry as Deputy Head. Previously, she worked at the Military Institute of Chemistry and Radiometry. Engaged in gamma spectrometry since 1996. Currently, she is working on natural radioactivity in raw and building materials, and conducts training in this field of research. She is the Manager of the Technically Accredited Laboratory of Natural Radioactivity Measurements in CLOR.

OLGA STAWARZ. M.Sc. - in 2001 graduated from the Faculty of Physics at Warsaw University with specialisation in the physics of elementary particles and fundamental interactions. Since 2002 she has been working at the Central Laboratory for Radiological Protection in the Department of Dosimetry. Initially, she dealt with the measurements of radon and its decay products, and worked as an Inspector of Radiological Protection. Currently, she is participating in work related to the radiological monitoring of the environment, gamma-spectrometry, the measurements of natural radioactivity of raw and building materials, and the measurements of radiation and dose assessment in the field, buildings and at workplaces. Quality Manager in Laboratory of Natural Radioactivity Measurements, the Central Laboratory for Radiological Protection, Department of Dosimetry. 
DR ANETA ŁUKASZEK-CHMIELEWSKA - ukończyła studia na Wydziale Fizyki Uniwersytetu Warszawskiego. Adiunkt w Zakładzie Fizyki i Chemii w Szkole Głównej Służby Pożarniczej w Warszawie. Prowadzi badania naukowe związane z palnością i dymotwórczością materiałów polimerowych, a także radioaktywnością komponentów środowiska.

MGR SYLWIA KRAWCZYŃSKA - zastępca dyrektora Centrum Naukowo-Badawczego Ochrony Przeciwpożarowej im. J. Tuliszkowskiego - Państwowego Instytutu Badawczego (CNBOP-PIB) ds. Badań i Rozwoju. Jest wykładowcą Szkoły Głównej Służby Pożarniczej (SGSP), absolwentką studiów magisterskich Wydziału Matematyki, Informatyki i Mechaniki Uniwersytetu Warszawskiego, studiów doktoranckich Kolegium Analiz Ekonomicznych Szkoły Głównej Handlowej, Szkoły Trenerów Biznesu oraz studiów podyplomowych m.in. na kierunkach: zarządzanie w stanach zagrożeń (SGSP) i nowoczesne metody zarządzania strategicznego (w Wyższej Szkole Zarządzania i Prawa im. H. Chodkowskiej). Od 2002 roku związana ze środowiskiem pożarniczym. Autorka kilkunastu publikacji z zakresu modelowania matematycznego i analiz ekonomicznych w obszarze inżynierii bezpieczeństwa, edukacji dla bezpieczeństwa oraz zarządzania zasobami ludzkimi w służbach mundurowych. Posiada doświadczenie w pracy w krajowych i międzynarodowych projektach naukowo-badawczych (5PR, 6PR, 7PR, Erasmus +).
ANETA ŁUKASZEK-CHMIELEWSKA, Ph.D. - graduated from the Faculty of Physics at Warsaw University. Assistant Professor in the Institute of Physics and Chemistry at the Main School of the Fire Service in Warsaw. She conducts researches in the field of flammability and the smoke production of polymer materials, as well as the radioactivity of environmental components.

SYLWIA KRAWCZYŃSKA, M.A. - Deputy Director for Research and Development in the Scientific and Research Centre for Fire Protection - the National Research Institute (CNBOP-PIB), an academic teacher in The Main School of the Fire Service (SGSP), a graduate of the Faculty of Mathematics, Informatics and Mechanics of the University of Warsaw, doctoral studies in the Collegium of Economic Analysis of the Warsaw School of Economics, postgraduate studies, among others Management in the United Threats in SGSP and Modern Methods of Strategic Management at the School of Management and Law and The School of Business Trainers. Since 2002, she has been engaged in the environment of firefighting and fire protection. The author of several publications in the field of mathematical modelling and economic analysis in the fields of safety engineering, safety education and human-resources management in the uniformed services. She has experience in the field of research projects at the national and international levels (FP5, FP6, FP7, Erasmus +). 


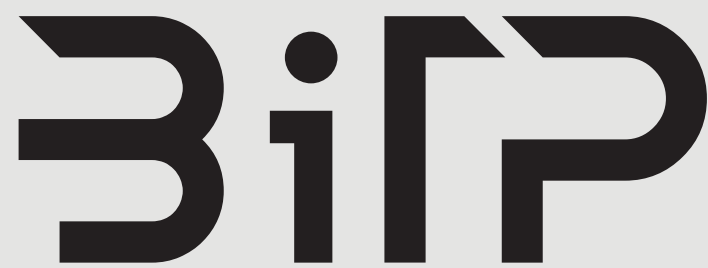

BEZPIECZEŃSTWO I TECHNIKA POŻARNICZA SAFETY \& FIRE TECHNIQUE

\section{МЫ ПРИГЛАШАЕМ ВАС К СОТРУДНИЧЕСТВУ}

Редакция ежеквартального журнала BiTP. Безопасность и Пожарная Техника

Предлагает Вам присылать проекты научных и обзорных статей, отчёты об исследованиях и случаях, а также научные рецензии, касающиеся широко понимаемой безопасности (на английском или русском языках).

Правила для Авторов доступны на интернет-странице http://bitp.cnbop.pl/ru.

Журнал индексирован в международных базах научных исследований

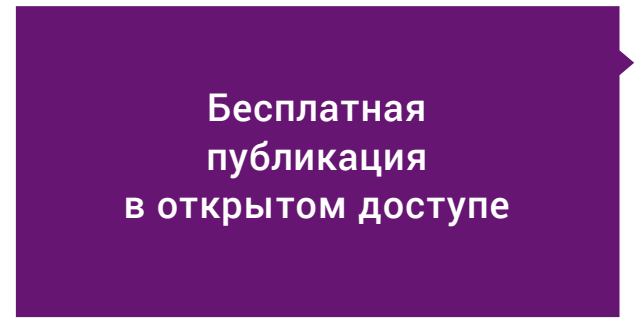

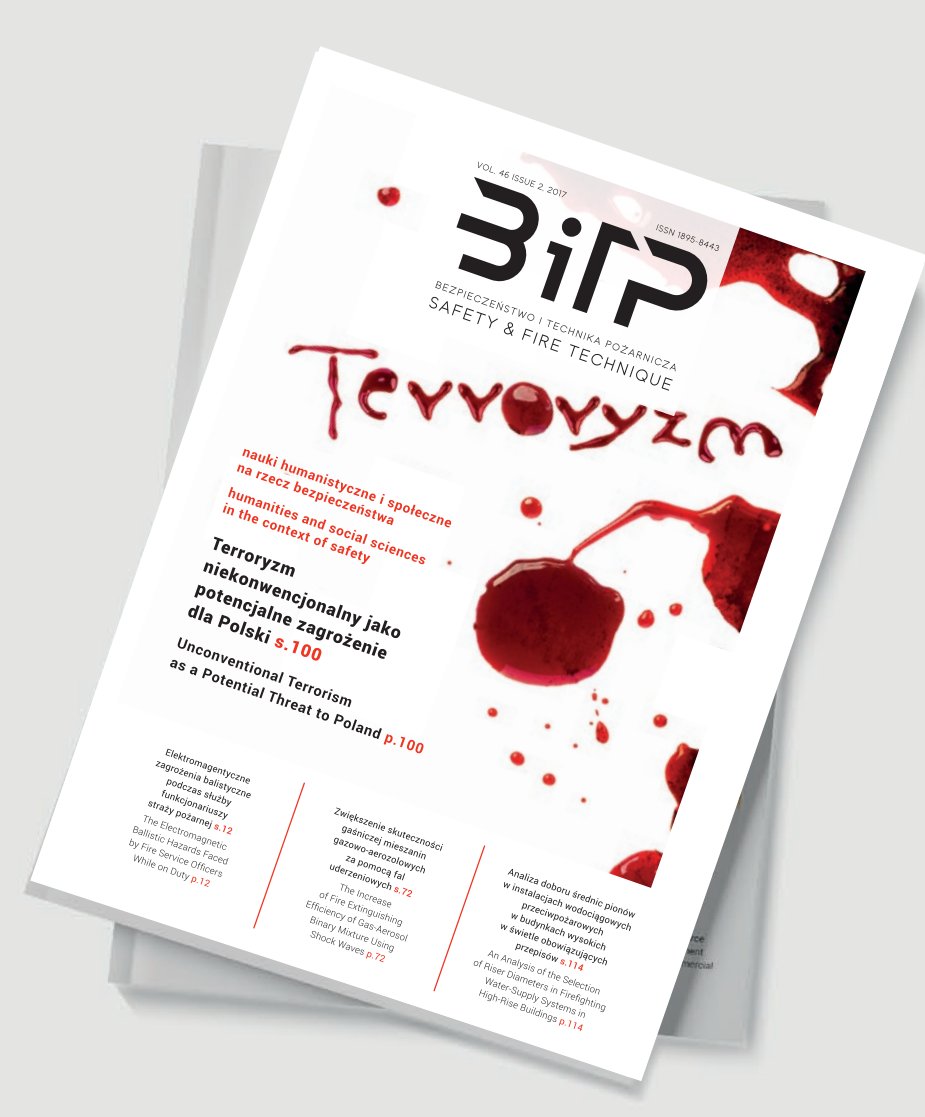
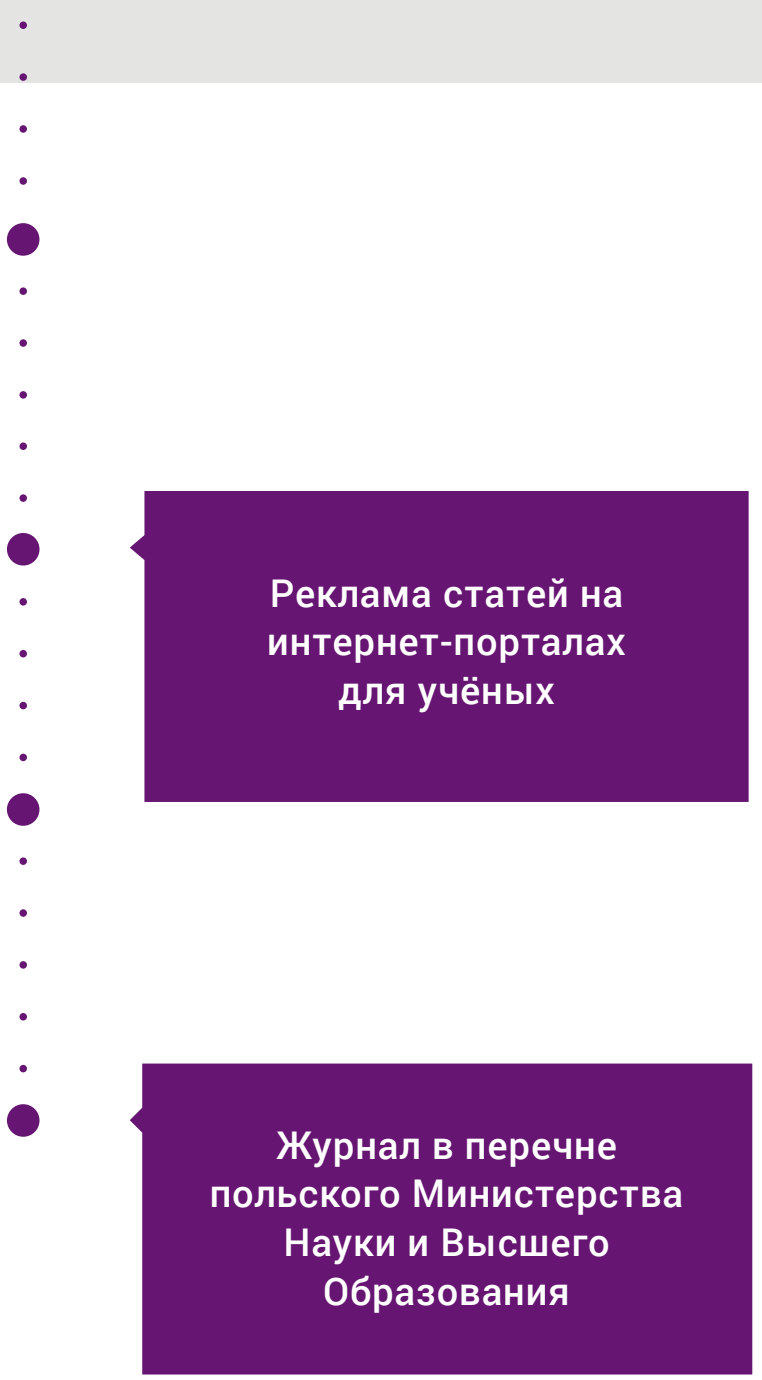